\title{
Pi for All
}

Missy, AJ and the Makers celebrated the CHAPS win over General Tso's Chicken and Hot and Sour Soup at Missy's favorite Chinese restaurant, Amazing Chow. Mr. Maker, AJ and G-ma shared the high points of the competition from the audience perspective, while Missy relived the suspenseful moments the team experienced when the microphones stopped working after lunch. They all laughed at the image Missy painted of Aj's posterboard bonnet.

Just as the fortune cookies came out, Ms.Jameson appeared."Matt! I'm so sorry I couldn't join you sooner," she said to Mr. Maker."I had some investigating to do! And, I hoped to have some news to share."

Missy and $\mathrm{AJ}$ exchanged perplexed looks.

"Do join us, Jennifer!" Mr. Maker said smiling widely. He leaned back and pulled a chair from a neighboring table and slid it between himself and G-ma.

Ms. Jameson settled into the chair and gave G-ma a kiss by way of greeting and said hello to the girls.

"Jenny, would you like to order some dinner? I'm sure they can get you something quickly," G-ma said.

"Oh. No thank you," Ms. Jameson said.

"Well, congratulations, dearie! The kids were great today-and so were you!" G-ma added.

"Thank you! You are right. The students did an outstanding job. I could not be more proud! The only blight on our day was the cyberbullying incident," Ms. Jameson added. 
Missy's jaw dropped open. She had not said anything to her dad and she hoped the whole thing would just fade away.

"You okay, Missy?" Mr. Maker asked.

Missy made a show of opening her fortune cookie and popping it into her mouth. "Mmm hmmm," she answered. AJ nudged her leg from under the table and looked at her with raised eyebrows.

Mr. Maker turned his attention to Ms. Jameson, "What's this about cyberbullying?"

"A few of the mathletes reported hurtful posts on their SocialMe pages earlier this school year. With CHAPS' zero tolerance policy, I was shocked to see another post today with name-calling," Ms. Jameson explained. "Missy showed me the comment calling her 'Missy-Math-Maker' and I raised the flag and let the principal know we needed to start an investigation."

"Oh no!" AJ jumped up from the table. "I'm so sorry." She pulled Missy's arm and grabbed her hand."That was me.I meant to cheer you on and let everyone know you were helping the team today and that you'd be great. OMG. It wasn't to bully you. Missy, I'm sorry if I hurt you," AJ said and dropped back into her chair sobbing into her hands. "Plus I was in a rush. I was making your poster and getting out to practice. Then catching a ride with G-ma."

"Wow," Missy said. "I thought it was weirdly supportive, but since you called me out using the name I hate, it hurt my feelings. I thought you were an anonymous bully. I worked so hard this year to show people that l'm not just about math-that I love other things like fashion-and wow. I don't know what to say," Missy said.

"Please forgive me," AJ said to Missy. “'’m really sorry that I hurt your feelings. I would never do that on purpose. I posted it from my cousin's account when I didn't have my phone with me. It's not anonymous. Oh Missy! You're my best friend!"

“Okay. Okay,” G-ma said."Everyone take a deep breath.”

"I-I forgive you," Missy said."I know you meant it in the best possible way."

AJ leaned over and side-hugged Missy. "I'm ready to face my consequences," AJ said to Ms. Jameson.

"Girls, I think you both agree this was not the cyberbullying that we initially thought it was," Ms. Jameson said and the two nodded. "So, we will close the investigation and move on from here. Agreed? We do have a more serious investigation going on that resulted in losing one member from the math team."

Missy and AJ nodded again. 
Mr. Maker scratched his head and straightened his pink and blue plaid bow tie. "I've never told you this Missy, but I had a nickname in school too, didn't I Jenn? Mom, do you remember?"

Ms. Jameson's face lit up, "Matt! I had completely forgotten about that."

"Oh, sonny!” G-ma said."Didn't your friends call you Matty-Math-Maker?"

"They sure did!” Mr. Maker said proudly. “To me, it was a badge of honor. With my interests in math and science, I have built a successful career as a software engineer."

Missy rolled her eyes. She never knew about her dad's nickname, but she had heard this math-path story many times before. Mr. Maker liked to remind Missy that studying math and science opened doors to wealth and success. And, after hearing Sarah DeMott earlier that day, Missy was starting to believe it!

Mr. Maker reached for a fortune cookie, cracked it open and read his fortune. "Listen to this," he said. "Math teachers love Pi for dessert."

"It does not say that!" Ms. Jameson grabbed the tiny strip of paper from Mr. Maker.

"I swear, it does!" Mr. Maker said putting his hand over his heart.

Ms. Jameson re-read the fortune. "It really does say that! Okay, then. I guess I will have some pie, after all!" she said.

"Make that pie for everyone," Mr. Maker said to the waiter. 